\title{
Analysis of Implementation of Fashion Learning in SMK Thailand and Indonesia
}

\author{
Sri Endah Wahyuningsih, Helena Rizki, Magdalena Nada \\ \{s.endah32@mail.unnes.ac.id ${ }^{1}$, helennarizki10@gmail.com², magdalenada@students.unnes.ac.id ${ }^{3}$ \}
}

Fashion Design Study Program, Home Economic Department, Technic Fakulty UNNES

\begin{abstract}
Education system between countries is not the same, each has a vision and mission in accordance with the interests of a country's human resources. The curriculum is created and developed to meet and answer the needs of the community for education and as a reference in learning. This study aims to analyze the implementation of fashion learning in the home economics department at the Luangprathanratnikorn Industrial and Community Education College Thailand school and at the fashion design expertise vocational school in Kota Semarang. The method of collection by interview is supported by documentation and observation. The results showed that learning to fashion learning based on the 2008 curriculum in Thailand supports the decentralization of education so that it focuses on intensive academic assessment by the school as well as through a national exam. The learning activities of fashion are theoretical and practical, emphasizing the objectives to be achieved, and the competencies that must be met and applying technology to be one of the educational goals. Students design products according to their creativity and practice in school. Learning in the Fashion Management expertise program at SMK N 6 Kota Semarang is based on the implementation of the basic core curriculum 2013 which must master compulsory and vocational group subjects (basic fields, basic competencies and vocational competencies). The teacher implements according to standard processes including, planning the implementation of learning, implementing the learning process, and evaluating learning outcomes. Learning activities are emphasized to be able to think critically or have HOTS (High Order Thingking Skills) and use scientific learning. Learning activities also include practical activities and theory using project-based learning methods supported by teaching factory. Assessment is carried out by the school, academics, industry and also through national examinations.
\end{abstract}

Keywords: Analysis, Curriculum Implementation, Learning, Fashion, Thailand, Indonesia.

\section{Introduction}

Each country has an educational goals, each of which is demonstrated by the existence of educational standards that must be achieved by every educational institution in any country, especially in Indonesia and Thailand, both of which are ASEAN member countries. The curriculum is an important reference that must be implemented during the learning process. The application of the curriculum in learning is an attempt to create directed, structured, effective and efficient learning activities. The application of the curriculum is carried out at all levels of education, by utilizing various elements contained in the curriculum, namely teaching materials, experiences, learning processes, learning competencies, and evaluation tools in the implementation of learning.

Vocational schools in Thailand have the same level as vocational schools in Indonesia, with a vision of creating a skilled workforce in accordance with their respective fields. Vocational education curriculum is developed by always referring to the principle of Relevance. The 
relevance of the curriculum is interpreted as the adaptive curriculum (Sanjaya, 2008). The curriculum has a function as an adjustment. The meaning of adjustment is the curriculum must have the ability to adjust to the development of society, science, technology, and the needs of the workforce. The development of the world of work is dynamic and changes rapidly in accordance with the development of science and technology. Relevance will connect the potential of existing employment and the ability of graduates to meet the requirements of the job. If graduates from vocational education cannot meet the requirements and needs that have been set employment, then vocational education is considered "failed" (Canavan, 2005; Hodge, 2011; Miller, 1985). Rapid changes in the world of work suggest that the curriculum needs to be constantly reviewed to see if there is still a match between what is taught in schools and the needs of the world of work. This relevance becomes a very important word to achieve the goals of vocational education itself. Vocational education curriculum must be designed according to the needs of the world of work. Vocational education curriculum and the needs of the world of work must have the principle of go hand in hand (Miller, 1985; Oloruntegbe, 2010). Vocational High Schools (SMK) as an important part of the vocational education system has the goal of "..... preparing students especially to work in certain fields". (National Education System Law No. 20 of 2003 article 15). The Education Attache of the Indonesian Embassy in Bangkok (2014: 6) stated that the opportunity for those who had worked to obtain a certificate of expertise was very open. Because of this need finally created a curriculum in Thailand 2008 which was formulated to provide opportunities for local communities and schools to take a role and orientation in preparing the school curriculum.

The Luangprathanratnikorn Industrial and Community Education College applies the 2008 curriculum in all of its educational studies, including vocational home economics. Halima Sidi (2014: 55) states that vocational home economics is a skill-oriented field of study that equips students with marketable skills that make them independent / self-employed. The subjects given in home economics vary greatly, including arranging flowers, decorating, cooking, sewing, and many others. One of the learning materials provided is making a mini dress in advanced sewing subjects. State Vocational School for fashion expertise in Semarang is SMK N 6 Kota Semarang, which applies the 2013 curriculum and implements teaching factory.

The formulation of the problem in this study are 1) how the implementation of sewing learning in Luangpratanratnikorn Industrial and Community Education College. 2) How is the implementation of learning to sew fashion in State Vocational School 6 according to the applicable 2013 curriculum.

\section{Research methode}

This study uses a qualitative research approach analysis method. Mills Haberman in Moleong Farida (2014: 23) which bases itself on natural paragraphs that focuses on efforts to find new elements of knowledge that did not exist in previous theories. Qualitative research refers to the analysis of non-mathematical data by collecting data through various means, namely interviews, observations, documents or archives, and tests. The validity of the data is determined using the triangulation method based on data sources, theories, and data obtained in the field. 


\section{Results and Discussion}

The curriculum is an educational program not a teaching program, which is a planned, programmed, and designed program that contains a variety of teaching materials and learning experiences both from the past, present and future (Dakir 2010: 2). The curriculum has a big influence on education because it is used as a guide and benchmark in learning in schools.

According to the Thai National Education Act 2542 (1999) Article 6 in managing education must be able to develop Thais who are physically, spiritually, intellectually, intellectually, as well as moral, cultural and customary in their daily lives so that they are able to coexist with others. Article 7 in the learning process must be able to plant true awareness about politics and governance in the democratic system of the King as Head of State. Defending human rights, following the constitution, respecting each other proudly as Thai citizens, safeguarding the public and state interests, including developing a culture of local products and universal science and preserving natural resources and the environment into creative, professional careers and curiosity in seeking knowledge.

There are several curriculums that are applied in Thailand, such as the 2001, 2003, 2008, and 2011 curriculums. In its application, Thailand seeks to answer the needs of the community by providing opportunities for schools to choose and apply the curriculum independently, adjusting to the school's own criteria. This freedom is arranged in such a way that the graduation of students is not determined by the national exam, but rather the school exam. Ten national economic and social development plans (2007-2011) emphasize the need to shift the focus of human development. This has become important for Thai people to be equipped with desirable moral values and intelligence. Students must be able to enjoy full physical, intellectual, emotional and spiritual development. Students will be able to adjust to changes that cannot be avoided, and lead to a transformation. These priorities are in line with the Thai Children's Ministry of Education's policy of guiding students towards the 21st century. Emphasis is placed on morality, preference for patriotism, analytical and creative thinking skills in technology, teamwork capacity and ability to live in peace and harmony in the world community (Thai Ministry of Education, 2008).

The study, monitoring and evaluation of the implementation of the 2001 basic education curriculum, together with the principles of the tenth National economic and social development plan for human capacity development, as well as the priorities recommended by the Ministry of education for youth development for the 21 st century led to the revision of this curriculum. As a result, the 2008 basic education core curriculum has been formulated for greater clarity and accuracy. Improvements were made to present the objectives and process of implementing the curriculum at the local level and in the education service school. Concise vision, goals, significant capacity and desired characteristics of students, and learning standards and indicators have been delivered, providing guidance for preparation The foundation of the 2008 core education curriculum is formulated so as to provide the community and school with a framework and orientation for preparing books. Teaching and learning activities organized for all Thai children's and young people at primary education level aim to improve the quality of students regarding the important knowledge and skills needed for their lives in a changing society. As such they will be empowered to seek further knowledge for continuous lifelong selfdevelopment.

The Thai Ministry of Education in The Basic Core Curriculum (2008) explains that the 2008 curriculum upholds the principle of decentralization with a vision to create harmony in development in all aspects of physical aspects, knowledge and morals, which ultimately leads to the development of the country. This vision can be achieved by fulfilling key student 
competencies, desired characteristics, and learning standards. The content of the key competencies includes (1) communication capacity to receive and send information; (2) the capacity of thinking to analyze, synthesis, constructive, and critical and systematic thinking; (3) problem-solving capacity; (4) capacity to apply life skills; (5) capacity to apply technology. Furthermore, the desired criteria from students include (1) love for the country, religion, and king; (2) honesty and integrity; (3) self-discipline; (4) a great desire to learn; (5) adherence to the principle of economic sufficiency; (6) dedication and commitment to work; (7) respect for Thailand; (8) public thinking.

The Luangprathanratnikorn Industrial and Community Education College chose to use the 2008 curriculum which was deemed most appropriate to the needs of the school. This is in accordance with the vision of the Luangpratanratnikorn Industrial and Community Education College as a vocational school to create skilled and professional workforce in their respective fields.

The 2008 curriculum is applied in all studies in the Luangprathanratnikorn Industrial and Community Education College, including advanced sewing subjects in home economics. Advanced sewing subjects are theoretical and practical subjects aimed at equipping students with sewing knowledge and skills.

One of the subject matter received in advanced sewing is making a mini dress, where new students are first taught to make a complete fashion, by developing knowledge from previous subjects where students make pieces of clothing separately.

The advanced sewing learning activity itself is a form of school to apply the key curriculum competencies of 2008 points 1, 4 and 5, namely the communication capacity of receiving and sending information, the capacity to apply life skills, and the capacity to apply technology.

Based on the results of recapitulation of data collected, it was concluded that the process of making a mini dress in advanced sewing subjects in the home economics department was simple, flexible, tolerant, referring to existing learning resources. Learning activities are supervised by the teacher, requiring students to always consult with the teacher in every step taken. This is due to the complexity of sewing techniques and the lack of complete learning resources outside of school, emphasizing the role of the teacher as a skilled person as the only concrete source of learning. Students are allowed to look for as many learning resources for later discussion in class, but are not allowed to directly use these learning resources before consulting with the teacher.

Students are not even allowed to bring work home, but are only allowed to do work at school during school hours to reduce the risk of cheating and provide more space for students to explore the world outside of school. This policy is a form of applying the third point in the desired student criteria in the 2008 curriculum, which is honesty and integrity.

The teacher does not give specific criteria to the mini dress that will be made, but instead frees students to be creative, one simple focus is enough. The teacher also does not provide specific criteria for selecting mini dress material, giving more space for students to choose independently, adjusting the characteristics of the mini dress they want to make. Most students prefer to use cotton because it is easy to sew.

Learning activities take place by upholding the use value of the product to be made, then making a mini dress tailored to the needs and desires of each student. Although the subject matter is making a mini dress, the teacher allows Muslim students to make maxi dresses so that the dress can be used by students everyday.

The high tolerance upheld in the advanced sewing class illustrates the second point in the desired student criteria in the 2008 curriculum, which is the love of religion. The teacher implements this to students without being pushy, calm and very understanding. This treatment 
also provides standards for student behavior to treat each other according to the teacher's reflection.

Each stage in making a mini dress is done with a simple structure, both in designing, making patterns, cutting, and sewing. Students are not required to design mini dresses using proportions of design, because the teacher is more focused on the description of the mini dress to be realized than the description on paper. Furthermore pattern making is done using the body size of each student with a practical pattern system. The pattern that has been made is then pinned to the material and then cut by giving the seam cut with $1.5 \mathrm{~cm}$ from the seam because the technique of finishing the cloth using the open seam is fixed. Before the pieces are sewn together, students are required to bare first in each rader line on the material, then put the pieces together with the material. This is intended to ensure accuracy when stitching each piece, so as to create a neat and accurate product after stitching using a machine.

The making of a mini dress is different for each student, adjusting to each design. One definite path is that each student completes the difficult part on each piece before putting it together with the other pieces. There are students who work their arms first, and there are students who work their bodies first.

Making mini dresses in advanced sewing applies the principle of decentralization which is upheld in the 2008 curriculum by freeing students to make mini dresses according to their individual needs.

Other research on curriculum application that has a connection with this research is a study from the 2015 Komnas Community titled New Trends in Higher Education Towards the 21st Century in Thailand. This research focuses on the circumstances as well as threats to higher education in Thailand. Prathip (2015: 17) concludes that in the next 5 years, what is critical for the higher education system is how to adopt a personal regulation strategy and increase effectiveness and effectiveness in dealing with scarcity of resources. Similar findings were also found in this study, that teachers are the main source of knowledge required to carry heavy responsibilities in daily learning and curriculum application. The high demand for responsibility and the difficulty of finding other sources of knowledge that are as accurate as the teacher creates difficulties for the teacher to meet the competency standards and lead to scarcity.

Another study was conducted by Jason L. C. in 2015 entitled Marketing Curriculum Preparedness for Thailand: Comparing Research for Marketing Curriculums is Colleges and Universities for Higher Education Institutions in Thailand. Jason (2015: 1022) found that Thai education needs to develop productivity in social responsibility, by enabling the marketing curriculum to stay centered on areas that are more effective than what is covered in the marketing mix. This finding is in accordance with the application of the 2008 curriculum which was made with the hope to answer the needs of the community.

Subsequent research was conducted by Sanit Srikoon et al in 2013 entitled Research Synthesis of Research-Based Learning for Education in Thailand. Sanit Srikoon et al. Quote Baldwin (2013: 916) that students in Thailand can develop strong intellectuals and practical connections between research boundaries by mastering learning itself. special education towards inclusive. The law mandates that (1) inclusive education be an option for the education of students with disabilities; (2) individuals with disabilities have the right to be included at every level of the education system from the beginning of the intervention and 12 years of basic education to the level of tertiary education; (3) it is against the law for schools to refuse entry to students with disabilities, and (4) students with disabilities must be provided with an Individual Education Plan (IEP) based on at least an annual update (Rajkijjanubaksa, 2008).

2013 Indonesian curriculum. 
The basic 2013's curriculum is a curriculum that was developed after the 2006 curriculum. 2013 curriculum focuses on improving the quality of education by balancing hard skills and soft skills through the ability of attitude, skills and knowledge in order to face the evolving global challenges. This curriculum is focused on the formation of competencies and characteristics of students, in the form of a blend of knowledge and skills, and attitudes that students can demonstrate as a form of understanding of the concepts they learn contextually. This curriculum began to be implemented in the 2014/2015 school year which emphasizes on eight standards. The eight standards are the Content Standards, Process Standards, Graduation Standards, Education and Education Staff Standards, Facilities and Infrastructure Standards, Financing Standards, Management Standards, and Education Assessment Standards. According to Hidayat (2013: 29) 2013 Curriculum orientation is an increase and balance between attitude competencies (attitude), skills (skills), and knowledge (knowledge). Professional teachers have pedagogical competencies, social competencies, personality competencies and professional competencies.

Teachers before teaching must have the provision of teaching skills such as: opening lessons, conditioning student learning situations, providing reinforcement, communicating with students, giving questions, giving feedback, assessing learning outcomes and closing lessons.

Opening the lesson is done by the teacher greeting, then conditioning students. After that the teacher gives apperception to students.

Conditioning the learning situation so that students are calm and able to concentrate fully, actions taken by the teacher such as the teacher not only stand or sit during the KBM, the teacher pays attention to all students, so that the attention of all students is focused on the learning process. The use of learning methods and media and variations in learning.

Giving reinforcement to students is a motivation so students become more interested in the lesson. The teacher provides reinforcement if the students 'answers are correct and to increase students' interest in the lesson. Strengthening is given verbally (verbally), nonverbally (body cues), and a mixture of both. Good communication will make the learning process run smoothly and the learning outcomes will be maximized. The methods and media used in learning must be in accordance with the material, the state of students in class and the condition of students' classrooms.

In delivering the material, the teacher must be able to manage variations in sound, technique or media. The teacher's voice must be loud and vary in tone and intonation, so that students can be heard and noticed. Sound variations are made so that students do not get bored and stay focused in learning.

Questions must be in accordance with the material provided. The questioning is intended so that the teacher knows whether students are able to accept the material being taught. The teacher always gives feedback so that all learning activities that have been carried out are in accordance with the objectives or not. The assessment of student learning outcomes is based on the assignments given and the daily tests. These daily assignments and tests can be given at the end of each chapter or at the end of each sub-topic taught.

Closing the lesson begins with concluding the material then giving home assignments for the material at the next meeting or assignments from what has been taught. Then close with greetings.Opening the lesson is the beginning of the teacher before starting a lesson. These activities can be in the form of reviews such as checking homework or student assignments with 
the aim to find out the readiness of students to continue the next lesson. Learning activities begin with opening activities starting with communication with students

The teacher is effectively able to communicate and explain learning activities in the classroom. Orientation on assignments must be completed at school by being monitored by a team of teachers. Teacher clarity in providing the context of the activity is important not only to make the activity effective, but also can increase understanding of the activity.

The teaching method in the learning process as one of the teacher's creative strategies uses a way of delivering lessons in the hope that subject matter can be accepted by students as well as possible. Some learning methods used by teachers include: lecture, question and answer, tutorial mastery, problem solving, project based and discussion.

The educational method applied is no longer in the form of teaching for the passing of the test (teaching to the test) but a comprehensive education that pays attention to social abilities, character, character, national cultural love, and so on. The media used in teaching is very varied according to the needs of the training course. The media that are always in the classroom are blackboards and textbooks, as well as LCDs, while the media practice subjects are adapted to the equipment needed to achieve the competency standards.

The Variative learning methods and strategies are carried out by the teacher in determining strategies to deliver a material that can be received by students optimally. Basically students will experience boredom if a given material requires heavy thinking, without any variation of the teacher in delivering the material or can be said to be monotonous delivery. These variations can be in the form of humor, intonation processing, pronunciation of words, quizzes, emphasis on material that is considered important so that it is easy to understand and utilizes assistive media as a means of material explanation. the teacher also provides reinforcement after completion of learning so that a shared decision is obtained by an in-flight decision term, the decision made during the activity. Vocational competencies of students include making decorations, designs, patterns, making industrial clothing and making costumed clothing.

Syllabus of the subjects of industrial fashion making has core competency 1 (KI 1) is a graduate of Appreciating and practicing the teachings of the religion he follows, KI 2 Living and practicing honest behavior, discipline, responsibility, caring, mutual cooperation, cooperation, tolerance, peace, courtesy, responsive and proactive and shows attitude as part of the solution to various problems in interacting effectively with the social and natural environment and in placing itself as a reflection of the nation in the world. KI 3 Understanding, applying, analyzing and evaluating factual, conceptual, basic operational and metacognitive knowledge in accordance with the field and scope of work Dressing on a technical, specific, detailed and complex level with respect to knowledge, technology, cultural arts and humanities in the context of development self potential as part of the family, school, community, national, regional and international, KI 4 Carry out specific tasks, using tools, information and work procedures that are commonly done and solve problems in accordance with the field of dressmaking, displaying performance below guidance with mutan and measured quantities according to work competency standards. Demonstrate the skills of reasoning, processing and serving effectively, creatively, productively, critically, independently, collaboratively, communicatively, and solutically in the abstract realm related to the development of what they learn in school, and able to carry out specifics under direct supervision. Demonstrate skills, perceive, readiness, imitate, proficient movements make natural movements in the realm of 
concrete related to the development of what they learn in school and are able to carry out specific tasks, under direct supervision.

The core competencies of subjects to make costumed clothing include KI 1. To appreciate and be grateful for the teachings of the religion that it adopts KI 2. To live and practice honest behavior, discipline, responsibility, care (mutual cooperation, cooperation, tolerance, peace), responsiveness and proactivity and being proactive, show attitude as part of the solution to various national problems in interacting effectively with the social and natural environment and in placing oneself as a reflection of the nation in the world community of IP 3. Understanding, applying, analyzing and evaluating factual, conceptual, and procedural knowledge and cognitive eyes in science, technology, art, culture, and humanities in humanity, nationality, state and civilization insights related to the causes of phenomena and events in specific fields of work to solve KI problems 4 Cultivate, serve, reason, and create in the realm of concrete and abstract domains related to the development of what he learned in the school independently, and is able to carry out specific tasks under direct supervision.

Some basic competencies related to sewing advanced clothing from KI 3 are 3.1 Analyzing party dresses 3.2 Formulating techniques to cut out party dress materials 3.8 Formulating the skirt cutting technique. Demonstrating how to iron the skirt. 3.10 Formulating the skirt sewing technique. 3. Demonstrating how to calculate the selling price of the skirt. The basic competency of KI 4 includes 4.1 Identifying party dresses (understanding, types, finishing / manufacturing techniques, characteristics / characteristics of material types) 4.2 Cutting the material of the party dress 4.3 Ironing the party dress 4.4 Sewing the party dress 4.5 Calculating the calculation of the sale price of the party dress 4.6 Packing the dress party.

The learning activities of tailoring fashion are theoretical and practical, emphasizing the objectives to be achieved, and the competencies that must be met and applying technology to be one of the educational goals. Students design products according to their creativity and practice in school. Learning in the Fashion Management expertise program at Vocational School Semarang is based on the implementation of the 2013 KTSP curriculum which must master compulsory and vocational group subjects (basic fields, basic competencies and vocational competencies). The teacher implements according to standard processes including, planning the implementation of learning, implementing the learning process, and evaluating learning outcomes. Learning activities are emphasized to be able to think critically or have HOTS (High Order Thingking Skill) and use scientific learning. Learning activities also include practical activities and theory using project-based learning methods supported by teaching factory. Assessment is carried out by the school, academics, industry and also through national examinations.

The learning process of sewing practices is done in several stages.

1. Design Determination

The design determination is carried out by a team of teachers who teach sewing practices or who teach sewing practice subjects at SMK N 6 Semarang by taking several samples made from both the teacher and some students. Samples taken about 1-2 designs that will be realized in class.

2. Make a Pattern 
The pattern is made first by the teacher's sewing team, then practiced to students by explaining how to make the pattern construction according to the sample pattern that was created. Generally the patterns taught in SMK N 6 Semarang use patterns of standard size.

3. Determination of ingredients

Material was determined by a team of sewing practice teachers who consulted with the department's financial department. Determination of the material has previously been done material estimates by making material design and price design.

4. Cutting material

The cutting of material is done en masse which is guided by the teacher by using an industrial cutting tool, after that it is budded, then marked by the students. Usually the marking step is done at home as homework.

5. Sewing Process

Sewing is done individually by using industrial sewing machines for classes XI and XII and manual machines for class $\mathrm{X}$. The sewing process is guided by the teacher who explains first at the beginning of learning, things to consider before sewing, such as sewing steps, reminds to use work clothes, provide trash bins. After students start sewing, the teacher examines one by one the student's sewing process and evaluates at the end of sewing learning. The sewing process is carried out entirely in school, it is due to the method used by the teacher, which is using the teaching demonstration method and also lectures.

6. $\quad$ Rating

The assessment is done before, during the process and after becoming a product. The final assessment was also carried out by involving outside parties, namely academics and industry / practitioners as a test of student competence.

Research on the curriculum was also conducted by Heri Retnawati et al in 2013. The study was titled Vocational High School Teachers' Difficulties in Implementation Assessment in Curriculum 2013 in Yogyakarta Province of Indonesia, which aims to describe the difficulties of vocational teachers in implementing the assessment system in the 2013 curriculum. the results of this study, Retni, et al (2016: 45) conclude that the key to teacher difficulties is the lack of comprehensive understanding of teachers about the 2013 curriculum, including the implementation of assessments, such as planning, implementing and reporting student achievement. Implementation of Curriculum 13 in SMK Indonesia Revised 2013 Curriculum Implementation 1) More students are required to be more active, creative and innovative, 2) assessment standards lead to competency-based assessments such as attitudes, skills and knowledge proportionally, 3) Teachers play the role of facilitators, 4) Student-centered learning becomes more active learning.

\section{Conclusion}

The application of learning to sew clothing all goes well and in accordance with aspects that have been arranged in the curriculum in preparing graduates to enter the workforce in accordance with their respective fields. Learning to make clothes at vocational schools in Thailand is based on the implementation of the 2008 curriculum while Indonesian and vocational schools implement the 2013 curriculum. Learning fashion that takes place has almost the same process starting from design, pattern, cutting, and sewing. The design process is more emphasized creativity, but for sewing techniques get more attention to be completed with the 
techniques conveyed by the teacher so that the work is done at school and should not be taken home. costumed fashion manufacture. Vocational competencies of students include making decoration. design, pattern, make clothes and make clothes customized. 


\section{References}

[1] Bamalli, H. S.: Competencies and Strategies for the Teaching of 21st Century Learners in Vocational Home Economics Education. International Letters of Social and Humanistic Sciences Vol. 8, No. 1, pp 50-55 (2014)

[2] Carter, J. L.: Marketing Curriculum Preparedness for Thailand: Comparing Research for Marketing Curriculums is Colleges and Universities for Higher Education Institutions in Thailand. Asia Pasific Journal of Marketing and Logistics Vol. 28, No. 5, pp. 1015-1030 (2015)

[3] Keiser C, Jonathan, et.all.: "Technical Education Curriculum Assessment" Journal of Vocational Education Research, Vol. 29, No. 3, pp.181-194 (2004)

[4] Komla M.E \& Ansah C.O.2011.: Linking Tertiary Institutions to industries: Evidence from the Vocational and Technical Education Departement of University of Cape Coast. International Journal of Vocational and Technical Education, Vol. 2, No. 5, pp. 53-60 (2011) [5] Komolmas, P.: New Trends in Higher Education Towards the 21st Century in Thailand. Assumption University, Bangkok (2015)

[6] Matthew O. A and Ede E.O.: Integration of New Technological Innovations in automobiles into the curriculum for Nigerian Technical College Programes. International Journal of Vocational and Technical Education, Vol. 2, No. 5, pp. 89-94 (2010)

[7] Miles \& Huberman.: Analisis data Kualitatif. (diterjemahkan Ole: Tjetjep Rohedi Rosidi). Universitas Indonesia, Jakarta (1992)

[8] Miller D. M.: Principles and A Philosophy for Vocational Education. The National Center for Research in Vocational Education The Ohio State University. Columbus, Ohio 43210 (1985)

[9] Nugrahani, F.: Metode Penelitian Kualitatif dalam Penelitian Pendidikan Bahasa. Cakra Books, Solo (2014)

[10] OBEC.: The Basic Core Curriculum B.E. 2551 (A.D. 2008). Ministry of Education, Bangkok (2008)

[11] Retnawati, H., S. Hadi. A. C. Nugraha.: Vocational High School Teachers Difficulties in Implementing the Assessment in Curriculum 2013 in Yogyakarta Province of Indonesia. International Journal of Instruction . Vol. 9, No. 1, pp. 33-48 (2016)

[12] Srikoon, S., T. Bunterm, J. Samranjai, \& J. Wattanathorn.: Research Synthesis of Research-Based Learning for Education in Thailand. Procedia - Social and Behavorial Sciences 116, pp. 913-917 (2014)

[13] Tanyathorn Mustafa karnas, Min zhuang .et.all.: Joaurna Educatioonal Planning no 35 Inclusive education plans and practices in China, Thailand, and Turkey. Vol. 25, No. 1, Saint Louis University (2015)

[14] Yunardi.: Sistem Pendidikan di Thailand. Kantor Atase, Kedutaan Besar Indonesia Bangkok, Bangkok (2014) 